\title{
Characteristics of Emissions from Reclamation of Solid-recovered Fuel (SRF) in a Cogeneration Plant
}

Aerosol and Air Quality Research

\section{OPEN ACCESS}

Received: May 17, 2021

Revised: July 29, 2021

Accepted: July 29, 2021

${ }^{*}$ Corresponding Author: kuoyiming@gmail.com

\section{Publisher:}

Taiwan Association for Aerosol Research

ISSN: $1680-8584$ print

ISSN: 2071-1409 online

Copyright: The Author(s). This is an open access article distributed under the terms of the Creative Commons Attribution License (CC BY 4.0), which permits unrestricted use, distribution, and reproduction in any medium, provided the original author and source are cited.

\author{
Yi-Ming Kuo ${ }^{1 *}$, Shih-Wei Huang ${ }^{2,3}$, Wang Yu Kuan ${ }^{4}$ \\ ${ }^{1}$ Department of Safety Health and Environmental Engineering, Chung Hwa University of Medical \\ Technology, Tainan 71703, Taiwan \\ ${ }^{2}$ Institute of Environmental Toxin and Emerging Contaminant, Cheng Shiu University, Kaohsiung \\ 83347, Taiwan \\ ${ }^{3}$ Center for Environmental Toxin and Emerging-Contaminant Research, Cheng Shiu University, \\ Kaohsiung 83347, Taiwan \\ ${ }^{4}$ She Ching Enterprise Co., Ltd., Tainan 74443, Taiwan
}

\section{ABSTRACT}

The feasibility of the replacement of coal with solid-recovered fuel (SRF) transformed from waste lubricants was investigated in this work. In addition, the emission characteristics of SRF reclamation in a cogeneration plant were evaluated. The raw waste lubricants collected from a factory that manufactures tinplate cans were pretreated, mixed with wood dust, bentonite, and coal ash, and then remolded into pellet SRF. The coal and remolded SRF were reclaimed in a cogeneration plant. The reclamation performance of the tested fuels was evaluated by analyzing the pollutant characteristics of the bottom ash, fly ash, and flue gas. The PCDD/F concentrations

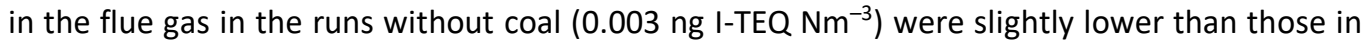
the runs with coal $\left(0.102 \mathrm{ng} \mathrm{I-TEQ} \mathrm{Nm}^{-3}\right.$ ). According to the monitoring data for $\mathrm{CO}, \mathrm{O}_{2}, \mathrm{NO}_{\mathrm{x}}$ and combustion efficiency, the substitution of SRF for coal improved the combustion conditions. The results showed that transformation of waste lubricant into SRF for reclamation is a promising method by which to take both waste treatment and energy regeneration into consideration.

Keywords: Combustion efficiency, Ash, SRF, Wood dust, Coal

\section{INTRODUCTION}

Due to rapid industrial development, the amount of waste being generated has increased dramatically in the last few decades. It is an important issue to dispose of this waste properly. For this reason, the priorities for waste treatment, as imposed by European strategies for waste management, include prevention, reuse, recycling, recovery of energy or resources, and disposal, in that order (Directive 2008/98/EC). Following these strategies, technological development for energy recovery from waste has flourished for the last few decades (Chang et al., 1999). Among these available technologies, the combustion process, typically called incineration, is the most common technology used to convert bio-waste into energy (Lombardi et al., 2015).

Bio-waste is usually incinerated to generate steam and then transformed into electricity via a cogeneration system or directly used in industrial processes (Vermeulen et al., 2011; Murer et al., 2011). Incineration is applied to dispose of various types of materials, including organic liquid waste, municipal solid waste, organic sludge, refuse-derived fuels (RDFs), and even unsorted residual waste (Arena, 2012; Myrin et al., 2014; Leme et al., 2014). In addition, incineration is an efficient technology that can be used to convert waste into energy and thus has several advantages. In general, it dramatically reduces the mass of waste by approximately 70 to $80 \%$ and the volume by approximately 80 to $90 \%$ and thus increases the service life of landfills (Consonni et al., 2005). It can also destroy organic pollutants and reduce greenhouse gas emissions more than anaerobic decomposition processes (Buekens and Cen, 2011; Psomopoulos et al., 2009). According to a life 
cycle analysis, incineration can also lighten environmental burdens because of the conversion of bio-waste into energy (Arena et al., 2003; Azapagic et al., 2004).

The RDF production process converts waste into fuel and makes it possible to acquire energy elsewhere. The solid waste is pretreated, mixed, and remolded into RDF in the form of pellets or short cylinders (Nasrullah et al., 2015) and can be transported to an RDF reclamation plant to generate energy or steam (Gug et al., 2015; Zhou et al., 2013). Because this is a flexible and convenient way to convert waste into energy, RDF reclamation through incineration has drawn worldwide attention and also is now regarded as a promising waste-to-energy technology that has been applied in the last decade (Rada and Andreottola, 2012). However, persistent organic pollutants, such as PCDD/Fs (polychlorinated dibenzo- $p$-dioxins and polychlorinated dibenzofurans), are unavoidably generated during the incineration process (Nam-Chol and Kim, 2017; Qiu et al., 2020), and these pollutants affect public health; for example, they can further have impacts on the eyes (Chang et al., 2020). The flue gas emitted from this process also requires proper disposal to prevent release into the ambient air. Therefore, it is essential to investigate the pollutant characteristics of the RDF reclamation process.

In the manufacturing of tinplate cans, a cutting oil, mainly composed of palm oil, often serves as a lubricant between the cutting tools and the tinplate. In addition to lubrication, the cutting oil also dissipates the heat generated during the cutting process so as to protect the cutting tools. After operating for a period of time, the lubricant gradually degrades and must be renewed. The waste lubricant has high heating value and thus is suitable for recycling as a fuel. However, in addition to palm oil and the original additives, the waste cutting oil still has water, metal scraps, and impurities that must be removed before transforming the waste lubricant into RDF.

Recently, wastes have often been regarded as dislocated resources, and, therefore, RDF is also called solid recovered fuel (SRF). In this study, a waste lubricant collected from a canned-food factory was pretreated, mixed with additives, and remolded into SRF. The characteristics of pollutants generated during the reclamation of SRF in a steam generation plant were investigated. In addition, the feasibility of replacement of coal with SRF was also evaluated.

\section{MATERIALS AND METHODS}

\subsection{Pretreatment of Waste Lubricant and Preparation of SRF}

The waste lubricant under consideration was collected from a canned-food factory in Tainan City, Taiwan. The waste lubricant was abandoned from a production line for manufacturing of tin cans and temporarily stored in 55-gallon oil drums in the plant. These drums were transported to Shi-Chang Co., Ltd. for further disposal. The waste lubricant was in a semi-solid state at room temperature and had to be heated to separate the impurities. The viscosity of the waste lubricant at different temperatures was measured via a viscometer (Brookfield, DV2T) to obtain the appropriate heating temperature for the separation process. Fig. 1 shows the viscosity of the waste lubricant at different temperatures. At room temperature, the waste lubricant was a semisolid ointment-like substance. When the waste lubricant was heated to $40^{\circ} \mathrm{C}$, it began to melt, and its viscosity was reduced to $180 \mathrm{cP}$. The viscosity of the waste lubricant was further reduced to about $40 \mathrm{cP}$ at $80^{\circ} \mathrm{C}$, and it was possible to dispose of the waste lubricant above this temperature. Fig. 2 shows flow chart of the SRF manufacturing process. The waste lubricant was heated to approximately $90^{\circ} \mathrm{C}$ to reduce its viscosity. Then, the melted waste lubricant was revolved at a rotation speed of $12,000 \mathrm{rpm}$ via centrifugation to remove the water content, metal scraps, and impurities.

Table 1 shows the properties of the raw and treated waste lubricants. The original waste lubricant comprised $24.6 \%$ water and $72.4 \%$ combustible content. The main composition of the combustible content was C $(56.7 \%), \mathrm{H}(7.74 \%)$, and $\mathrm{O}(7.27 \%)$, and the low heating value of the raw waste lubricant was $6,940 \mathrm{kcal} \mathrm{kg}^{-1}$. After the treatments, the combustible content increased to $88.2 \%$ and was mainly composed of $\mathrm{C}(77.1 \%), \mathrm{H}(4.69 \%)$, and $\mathrm{O}(6.22 \%)$. The water content in the treated waste lubricant was reduced to $8.6 \%$, and, thus, its low heating value increased to $8,690 \mathrm{kcal} \mathrm{kg}^{-1}$. Most of the metals were removed from the waste lubricant, and the levels of anthropogenic metals, including $\mathrm{Cd}, \mathrm{Cr}, \mathrm{Cu}, \mathrm{Mn}, \mathrm{Ni}, \mathrm{Pb}$, and $\mathrm{Zn}$, were all reduced to less than $500 \mathrm{mg} \mathrm{kg}^{-1}$. 


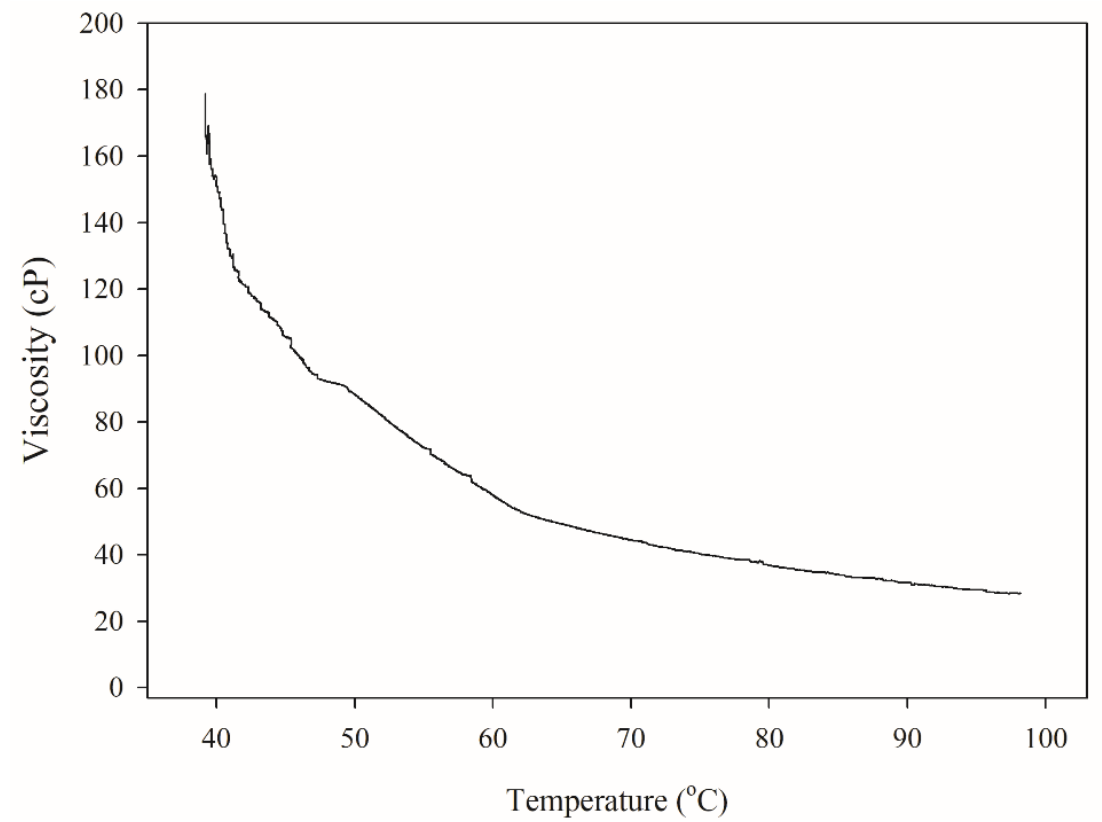

Fig. 1. Viscosity of waste palm oil versus different temperatures.

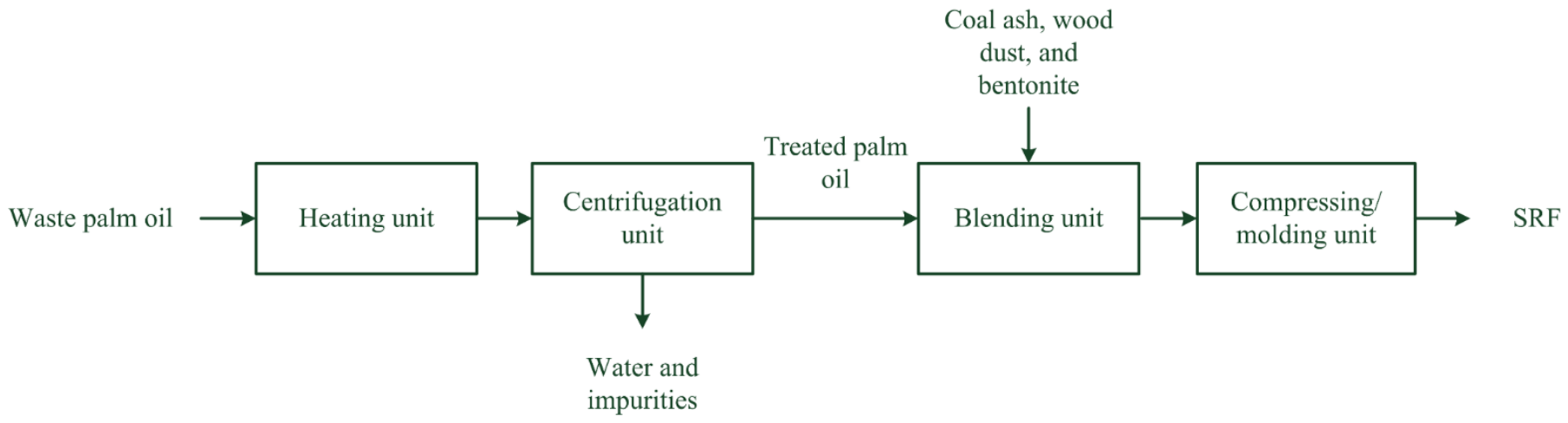

Fig. 2. Process for transformation of waste palm oil into SRF.

Before being cooled down, the treated waste lubricant was blended with wood dust, coal ash, and bentonite. The properties of SRF additive are shown in Table 2. The wood dust was $88.4 \%$ combustible content, and the metals were all in trace amounts. It had a low heating value of $3,300 \mathrm{kcal} \mathrm{kg}^{-1}$, which played a role to adjust the heating value. The levels of $\mathrm{Cl}$ and $\mathrm{S}$ in the wood dust were 2,650 and $6,810 \mathrm{mg} \mathrm{kg}^{-1}$, respectively, which probably came from the paint on the original waste wood. The coal ash had a $90.2 \%$ ash content, which was used to improve the physical strength of the SRF. Bentonite, mainly composed of montmorillonite, is an absorbent aluminum phyllosilicate clay. Except for Si, bentonite is mainly composed of $\mathrm{Al}\left(13,900 \mathrm{mg} \mathrm{kg}^{-1}\right)$, $\mathrm{Ca}\left(23,300 \mathrm{mg} \mathrm{kg}^{-1}\right)$, and Fe $\left(26,500 \mathrm{mg} \mathrm{kg}^{-1}\right)$, which are all crust metals. The bentonite expanded and became adhesive when it was mixed with water, and thus, it served as a binder for the mixture. The mixture was compressed at a pressure of $20 \mathrm{~kg} \mathrm{~cm}^{-2}$ into a pellet-shaped SRF with a diameter of approximately $5 \mathrm{~cm}$.

Table 3 shows the formulas for the various SRFs. The mass fraction of the treated waste lubricant, which ranged from $33 \%$ to $70 \%$, was the main operational factor. The wood dust served as an additive, and the treated waste lubricant and wood dust accounted for approximately $90 \%$ of the mass of the SRF. The percentage of the added coal ash ranged from 5 to $10 \%$, which improved the physical strength of the mixture, and $0.5 \%$ bentonite was consistently added to bind the mixture. The theoretical low heating value was calculated from adding the products of the mass fractions and the low heating value of each material. The relative errors between the theoretical 
Table 1. Properties of the raw and treated waste lubricants $(n=3)$.

\begin{tabular}{|c|c|c|c|c|c|}
\hline \multirow{2}{*}{ Item } & & \multicolumn{2}{|c|}{ Raw waste lubricants } & \multicolumn{2}{|c|}{ Treated waste lubricants } \\
\hline & & Average & RSD (\%) & Average & RSD (\%) \\
\hline \multirow[t]{3}{*}{ Proximate analysis } & Water (\%) & 24.6 & 13.7 & 8.6 & 11.5 \\
\hline & Ash content (\%) & 2.9 & 12.8 & 3.22 & 13.7 \\
\hline & Combustible content (\%) & 72.4 & 3.05 & 88.2 & 16.8 \\
\hline \multirow[t]{6}{*}{ Combustible content } & $\mathrm{C}(\%)$ & 56.7 & 15.4 & 77.1 & 16.6 \\
\hline & $\mathrm{H}(\%)$ & 7.74 & 17.8 & 4.69 & 18.7 \\
\hline & $\mathrm{O}(\%)$ & 7.27 & 11.5 & 6.22 & 12.3 \\
\hline & $\mathrm{N}(\%)$ & 0.05 & 22.3 & 0.03 & 28.6 \\
\hline & $\mathrm{S}(\%)$ & 0.04 & 27.7 & 0.05 & 15.2 \\
\hline & $\mathrm{Cl}(\%)$ & 0.01 & 14.1 & 0.01 & 17.3 \\
\hline \multirow[t]{10}{*}{ Metals } & $\mathrm{Al}\left(\mathrm{mg} \mathrm{kg}^{-1}\right)$ & 9,700 & 13.8 & 1,210 & 18.6 \\
\hline & $\mathrm{Ca}\left(\mathrm{mg} \mathrm{kg}^{-1}\right)$ & 3,140 & 8.0 & 2,850 & 20.1 \\
\hline & $\mathrm{Cd}\left(\mathrm{mg} \mathrm{kg}^{-1}\right)$ & 6.8 & 12.4 & 3.47 & 15.7 \\
\hline & $\mathrm{Cr}\left(\mathrm{mg} \mathrm{kg}^{-1}\right)$ & 75.4 & 17.7 & 31.6 & 18.9 \\
\hline & $\mathrm{Cu}\left(\mathrm{mg} \mathrm{kg}^{-1}\right)$ & 804 & 15.5 & 357 & 15.6 \\
\hline & $\mathrm{Fe}\left(\mathrm{mg} \mathrm{kg}{ }^{-1}\right)$ & 18,500 & 8.7 & 3,670 & 21.3 \\
\hline & $\mathrm{Mn}\left(\mathrm{mg} \mathrm{kg}^{-1}\right)$ & 44.5 & 4.5 & 12.3 & 15.8 \\
\hline & $\mathrm{Ni}\left(\mathrm{mg} \mathrm{kg}^{-1}\right)$ & 283 & 37.6 & 72.8 & 16.4 \\
\hline & $\mathrm{Pb}\left(\mathrm{mg} \mathrm{kg}^{-1}\right)$ & 35 & 86.1 & 12.0 & 8.9 \\
\hline & $\mathrm{Zn}\left(\mathrm{mg} \mathrm{kg}^{-1}\right)$ & 850 & 25.4 & 105 & 12.3 \\
\hline \multicolumn{2}{|c|}{ Low heating value $\left(\mathrm{kcal} \mathrm{kg}^{-1}\right)$} & 6,940 & 11.5 & 8,690 & 18.4 \\
\hline
\end{tabular}

Table 2. Properties of the additives for SRF $(n=3)$.

\begin{tabular}{|c|c|c|c|c|c|c|c|}
\hline \multirow{2}{*}{ Item } & & \multicolumn{2}{|c|}{ Wood dust } & \multicolumn{2}{|c|}{ Bentonite } & \multicolumn{2}{|c|}{ Coal ash } \\
\hline & & Average & RSD (\%) & Average & RSD (\%) & Average & RSD (\%) \\
\hline \multirow[t]{3}{*}{ Proximate analysis } & Water content (\%) & 11.7 & 10.8 & 9.5 & 1.90 & 0.3 & 17.6 \\
\hline & Ash content (\%) & 0.43 & 13.4 & 10.1 & 26.8 & 90.2 & 11.3 \\
\hline & Combustible content (\%) & 88.4 & 15.3 & 80.4 & 0.198 & 9.57 & 8.98 \\
\hline \multirow[t]{12}{*}{ Elements } & $\mathrm{Al}\left(\mathrm{mg} \mathrm{kg}^{-1}\right)$ & 1,060 & 73.7 & 13,900 & 21.4 & 1,220 & 2.0 \\
\hline & $\mathrm{Ca}\left(\mathrm{mg} \mathrm{kg}^{-1}\right)$ & 10.0 & 0.6 & 23,300 & 12.5 & 256 & 9.2 \\
\hline & $\mathrm{Cd}\left(\mathrm{mg} \mathrm{kg}^{-1}\right)$ & 0.9 & 90.6 & 2.61 & 14.7 & N.D. & N.A. \\
\hline & $\mathrm{Cr}\left(\mathrm{mg} \mathrm{kg}^{-1}\right)$ & N.D. & N.A. & 58 & 8.5 & N.D. & N.A. \\
\hline & $\mathrm{Cu}\left(\mathrm{mg} \mathrm{kg}^{-1}\right)$ & 6.3 & 25.2 & 10.5 & 55.5 & 6.27 & 21.4 \\
\hline & $\mathrm{Fe}\left(\mathrm{mg} \mathrm{kg}^{-1}\right)$ & 131.9 & 9.1 & 26,500 & 7.3 & 331 & 9.5 \\
\hline & $\mathrm{Mn}\left(\mathrm{mg} \mathrm{kg}^{-1}\right)$ & 58.2 & 10.1 & 251 & 5.1 & N.D. & N.A. \\
\hline & $\mathrm{Ni}\left(\mathrm{mg} \mathrm{kg}^{-1}\right)$ & 2.66 & 12.4 & 98.7 & 5.7 & 11.8 & 17.0 \\
\hline & $\mathrm{Pb}\left(\mathrm{mg} \mathrm{kg}^{-1}\right)$ & 9.05 & 24.5 & 23.9 & 45.5 & 8.33 & 7.2 \\
\hline & $\mathrm{Zn}\left(\mathrm{mg} \mathrm{kg}^{-1}\right)$ & 27.6 & 25.3 & 267 & 16.5 & 18.9 & 39.8 \\
\hline & $\mathrm{Cl}\left(\mathrm{mg} \mathrm{kg}^{-1}\right)$ & 2,650 & 15.4 & 1.2 & 18.8 & 807 & 32.1 \\
\hline & $\mathrm{S}\left(\mathrm{mg} \mathrm{kg}^{-1}\right)$ & 2,810 & 18.7 & 504 & 12.1 & 529 & 18.9 \\
\hline \multicolumn{2}{|c|}{ Low heating value $\left(\mathrm{kcal} \mathrm{kg}^{-1}\right)$} & 3,300 & 15.2 & 3,650 & 8.6 & 63.7 & 10.6 \\
\hline
\end{tabular}

Table 3. Formulas for the SRFs in different runs.

\begin{tabular}{|c|c|c|c|c|c|c|c|c|}
\hline Item & Run-1 & Run-2 & Run-3 & Run-4 & Run-5 & Run-6 & Run-7 & Run-8 \\
\hline Treated waste lubricant (\%) & 33 & 40 & 45 & 50 & 55 & 60 & 64 & 70 \\
\hline Wood dust (\%) & 60 & 50 & 42 & 40 & 35 & 35 & 30 & 19.5 \\
\hline Bentonite (\%) & 0.5 & 0.5 & 0.5 & 0.5 & 0.5 & 0.5 & 0.5 & 0.5 \\
\hline Coal ash (\%) & 6.5 & 9.5 & 12.5 & 9.5 & 9.5 & 4.5 & 5.5 & 10.0 \\
\hline Measured low heating value $\left(\mathrm{kcal} \mathrm{kg}^{-1}\right)$ & 4,450 & 4,610 & 5,030 & 5,620 & 5,610 & 5,840 & 6,210 & 6,040 \\
\hline Theoretical low heating value $\left(\mathrm{kcal} \mathrm{kg}^{-1}\right)$ & 4,870 & 5,151 & 5,324 & 5,690 & 5,960 & 6,359 & 6,575 & 6,754 \\
\hline Relative error (\%) & -8.62 & -10.7 & -6.08 & -1.59 & -6.04 & -8.80 & -5.71 & -11.2 \\
\hline
\end{tabular}




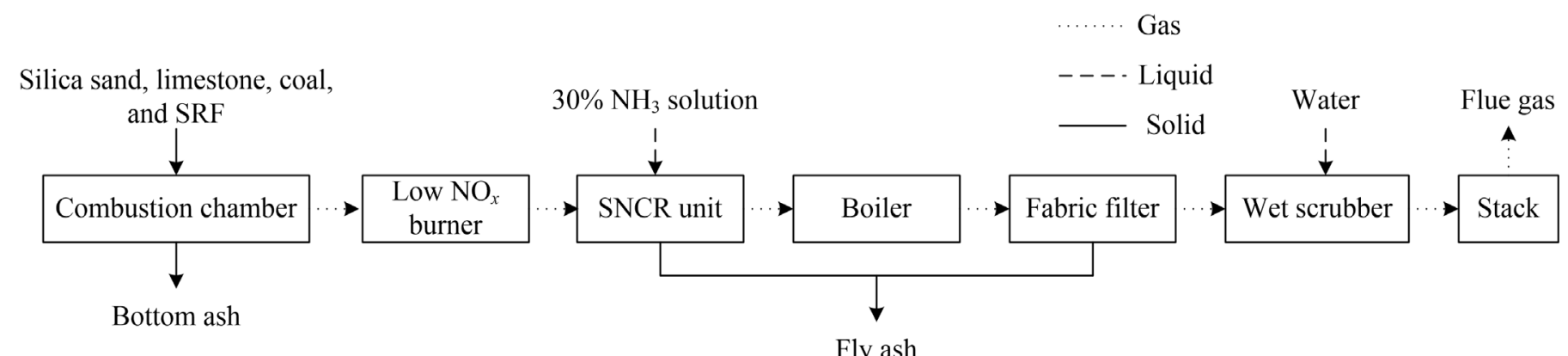

Fig. 3. Process flow at the cogeneration plant for the reclamation of SRF.

and measured low heating values were mostly less than $10 \%$. To meet the fuel specification requirements for the cogeneration plant, the ingredients in the SRF and their proportions in the experiments were as follows: treated waste lubricant (60 wt\%), wood dust (35 wt\%), coal ash (4.5\%), and bentonite ( $0.5 \mathrm{wt} \%)$.

\subsection{Reclamation of SRF in a Steam Generation Plant}

The remolded SRF was transported to a cogeneration plant located in Taichung City. The process flow diagram is shown in Fig. 3 . The input materials were fed via a conveyor belt into a fluidized-bed combustion chamber with a capacity of 2 ton $\mathrm{hr}^{-1}$. Silica sand and limestone were added to distribute the heat uniformly over the combustion chamber. The worn supplemental materials, silica sand and limestone, were discharged from the furnace with the bottom ash or fly ash. The original input material used for feed at this cogeneration plant was coal, with a low heating value of approximately $5,500 \mathrm{kcal} \mathrm{kg}^{-1}$. Therefore, the formulas for the SRFs chosen for use in the tests were those made in run-3. The combustion tests were divided into control and experimental groups, and each group underwent three tests. The input material for the control group was $100 \%$ coal. For the experimental group, SRF and coal accounted for $40 \%$ and $60 \%$ of the input material mass, respectively. The combustion temperature was maintained at 750 to $800^{\circ} \mathrm{C}$, and $\left[\mathrm{O}_{2}\right]$ was controlled at under $10 \%$ to reduce the formation of $\mathrm{NO}_{\mathrm{x}}$. The combustion residue was discharged into the bottom ash pit and cooled using water. The flue gas was emitted from the furnace into a low- $\mathrm{NO}_{x}$ burner to inhibit $\mathrm{NO}_{x}$ formation at 800 to $850^{\circ} \mathrm{C}$. The flue gas passed through an SNCR (selective non-catalytic reduction) unit with an injection of $30 \% \mathrm{NH}_{3}$ solution, which is a common process used to reduce $\mathrm{NO}_{x}$ (Yue et al., 2020). The reduction reaction is shown as Eq. (1).

$4 \mathrm{NO}+4 \mathrm{NH}_{3}+\mathrm{O}_{2} \rightarrow 4 \mathrm{~N}_{2}+6 \mathrm{H}_{2} \mathrm{O}$

The flue gas then passed into a boiler. The generated amount, the rated working pressure, and the rated temperature of the steam were 10 to 12 ton $\mathrm{hr}^{-1}, 20 \mathrm{~kg} \mathrm{~cm}^{-2}$, and 180 to $200^{\circ} \mathrm{C}$, respectively. The flue gas was cooled to approximately $180^{\circ} \mathrm{C}$ and passed through into a fabric filter with a filtering velocity of $0.5 \mathrm{~m} \mathrm{~min}^{-1}$. Next, a wet scrubber was set up to remove acid gas $\left(\mathrm{HCl}\right.$ and $\left.\mathrm{SO}_{2}\right)$ via an injection of a $40 \% \mathrm{NaOH}$ solution with liquid to gas ratio of $2 \mathrm{~L} \mathrm{~m}^{-3}$, and the treated flue gas was then emitted to the ambient air. The fly ashes emitted from the boiler, the fabric filter, and the wet scrubber were all collected together as the total fly ash.

\subsection{Sampling of Flue Gas and Solid Specimens}

The flue gas was sampled at the stack. Before sampling the PCDD/Fs, the collection efficiency of the sampling train was measured with the addition of specific amounts of surrogate standards pre-labeled with isotopes, including ${ }^{37} \mathrm{C}_{14}-2,3,7,8-\mathrm{TeCDD},{ }^{13} \mathrm{C}_{12}-1,2,3,4,7,8-\mathrm{HxCDD},{ }^{13} \mathrm{C}_{12}-2,3,4,7,8$ PeCDF, ${ }^{13} \mathrm{C}_{12}-1,2,3,4,7,8-\mathrm{HxCDF}$, and ${ }^{13} \mathrm{C}_{12}-1,2,3,4,7,8,9-\mathrm{HpCDF}$. A standard sampling procedure was used in the experiments to measure the PCDD/Fs in the flue gas, following the instructions issued by the TEPA, for which the detailed procedures were reported in a previous study (TEPA, 2010; Kuo et al., 2019). 
The sampling and analysis of the metals in the flue gas followed the standard method established by the NIEA A302.72C (TEPA, 2006). A sampling train with a cooling device, a holder with a fiberglass filter, a series of impingers, a pump, and a flow meter was used for sampling the flue gas isokinetically. The average flow rate was set at $5 \mathrm{~L} \mathrm{~min}^{-1}$, and the sampling time was more than $3 \mathrm{hrs}$. The sampling and analytical procedure used to measure the metals in the flue gas were reported in previous studies in detail (Tsai et al., 2018; Chen et al., 2018).

A flue gas analyzer (Horiba, PG-350) was used to continuously measure the concentrations of $\mathrm{O}_{2}, \mathrm{CO}_{2}, \mathrm{CO}, \mathrm{NO}_{\mathrm{x}}$, and $\mathrm{SO}_{\mathrm{x}}$ in the flue gas. In addition, bottom ash and mixed fly ash were collected from the ash pits for further analysis.

\subsection{Analyses of PCDD/Fs, Metal Content, and Metal Leaching Behavior}

The pretreatment of the solid specimens used in the PCDD/F analysis was conducted using the following steps: 1) Extraction with a mixed solvent of half-and-half $n$-hexane and dichloromethane, 2) determining the nitrogen-blowing concentration, 3) cleanup via silica gel, and 4) determining the nitrogen-blowing re-concentration. The solutions were then analyzed using a high-resolution gas chromatograph (Hewlett-Packard 6970 Series gas, CA) and a high-resolution mass spectrometer (Micromass Autospec Ultima, Manchester, UK) to identify 17 PCDD/F species. The detailed procedures for the PCDD/F analysis were reported in previous studies (Tsai et al., 2018; Kuo et al., 2019).

The procedure used to determine the metal content in the solid specimens was modified from the standard method given in NIEA R317.11C (TEPA, 2014). The solid specimens were all pulverized to particle sizes smaller than $150 \mu \mathrm{m}$ (mesh 100) to ensure consistent digestion efficiency. The pulverized solid specimens $(\sim 0.1 \mathrm{~g})$ were held in Teflon vessels to which a mixed acid composed of $3 \mathrm{~mL} \mathrm{HCl}$ (32 wt\%) and $3 \mathrm{~mL} \mathrm{HNO}$ (67 wt\%) was added. The vessels were sealed and heated using a microwave digester (MARS Xpress, CEM). The heating program was as follows: heating to $210^{\circ} \mathrm{C}$ at a rate of $6^{\circ} \mathrm{C} \mathrm{min}-1$, holding isothermally for $20 \mathrm{~min}$, and cooling down to room temperature with ventilation. The digests were diluted with deionized water to $25 \mathrm{~mL}$ and then filtrated using mixed cellulose ester filters.

A toxicity characteristic leaching procedure (TCLP) was used to evaluate the hazardous metal mobility of the bottom ash and mixed fly ash. An extraction solution ( $\mathrm{pH}=4.93 \pm 0.05)$ was prepared using $5.7 \mathrm{~mL}$ of glacial acetic acid and $64.3 \mathrm{~mL}$ of $\mathrm{NaOH}$ solution $(1 \mathrm{~N})$, which were mixed and diluted to $1000 \mathrm{~mL}$ using deionic water. The pulverized specimen and the prepared exaction solution were mixed at a mass ratio of solid:liquid $=1: 20$. The mixture was rotated overhead at a rate of 30 turn $\mathrm{min}^{-1}$ for $24 \mathrm{hrs}$. The leachate was separated from the solid specimens, acidified by adding $0.5 \mathrm{~mL}$ of concentrated $\mathrm{HNO}$, and filtered for the metal analysis. The detailed steps, including preparation of the extraction solution, the leaching conditions, dilution, digestion, and filtration, all followed the standard procedure regulated by the TEPA (2016). The metal concentrations, including $\mathrm{Al}, \mathrm{As}, \mathrm{Ba}, \mathrm{Ca}, \mathrm{Cd}, \mathrm{Cr}, \mathrm{Cu}, \mathrm{Fe}, \mathrm{Hg}, \mathrm{Mn}, \mathrm{Ni}, \mathrm{Pb}, \mathrm{Se}$, and $\mathrm{Zn}$ in the solution and the digests were measured using atomic absorption spectroscopy (AAS, Agilent technologies 55AA).

\section{RESULTS AND DISCUSSION}

\subsection{Property of Input Materials}

The properties of the SRF and coal are shown in Table 4. The SRF had 77.8\% combustible content, $9.6 \%$ water content, and $12.6 \%$ water content. The coal had approximately an equal fraction of combustible content but a higher fraction of ash content than the SRF. The low heating value of the SRF $\left(5,690 \mathrm{kcal} \mathrm{kg}^{-1}\right)$ was slightly higher than that of coal $\left(5,340 \mathrm{kcal} \mathrm{kg}^{-1}\right)$. In terms of the content of metal species, the SRF had Fe $\left(3,950 \mathrm{mg} \mathrm{kg}^{-1}\right)$, Ca $\left(3,220 \mathrm{mg} \mathrm{kg}^{-1}\right)$, and Al $\left(2,220 \mathrm{mg} \mathrm{kg}^{-1}\right)$, and the coal had $\mathrm{Mn}\left(33,100 \mathrm{mg} \mathrm{kg}^{-}\right)$, Fe $\left(24,700 \mathrm{mg} \mathrm{kg}^{-1}\right)$, and Ca $\left(3,650 \mathrm{mg} \mathrm{kg}^{-1}\right)$.

\subsection{Pollutant Concentrations in the Flue Gas}

The concentrations of the air pollutants in the flue gas are shown in Table 5. For Group I, the average concentrations of $\left[\mathrm{O}_{2}\right],\left[\mathrm{CO}_{2}\right]$, and $[\mathrm{CO}]$ in the flue gas were $8.3 \%, 11.5 \%$, and $45 \mathrm{ppm}$, respectively. The flue gas in Group II had $\left[\mathrm{O}_{2}\right],\left[\mathrm{CO}_{2}\right]$, and $[\mathrm{CO}]$ at concentrations of $6.5 \%, 12.4 \%$, and 35 ppm, respectively. The averaged combustion efficiencies $\left(=\left(\left[\mathrm{CO}_{2}\right] /\left[\mathrm{CO}_{2}\right]+[\mathrm{CO}]\right) \times 100 \%\right)$ 
Table 4. Properties of the input materials.

\begin{tabular}{|c|c|c|c|c|c|}
\hline \multirow{2}{*}{ Item } & & \multicolumn{2}{|c|}{ Coal } & \multicolumn{2}{|c|}{ SRF } \\
\hline & & Average & $\mathrm{RSD}(\%)$ & Average & RSD(\%) \\
\hline \multirow[t]{3}{*}{ Proximate analysis } & Water content (\%) & 5.2 & 17.2 & 12.6 & 7.8 \\
\hline & Ash content $(\%)$ & 16.3. & 28.5 & 9.6 & 25.7 \\
\hline & Combustible content (\%) & 78.5 & 24.4 & 77.8 & 3.7 \\
\hline \multirow[t]{12}{*}{ Metals } & $\mathrm{Al}\left(\mathrm{mg} \mathrm{kg}^{-1}\right)$ & 548 & 16.3 & 2,220 & 8.23 \\
\hline & $\mathrm{Ca}\left(\mathrm{mg} \mathrm{kg}^{-1}\right)$ & 3,650 & 18.3 & 3,220 & 27.7 \\
\hline & $\mathrm{Cd}\left(\mathrm{mg} \mathrm{kg}^{-1}\right)$ & 3.82 & 15.7 & 1.77 & 36.3 \\
\hline & $\mathrm{Cr}\left(\mathrm{mg} \mathrm{kg}^{-1}\right)$ & 7.32 & 16.1 & 17.4 & 21.0 \\
\hline & $\mathrm{Cu}\left(\mathrm{mg} \mathrm{kg}^{-1}\right)$ & 25.0 & 22.9 & 155 & 27.4 \\
\hline & $\mathrm{Fe}\left(\mathrm{mg} \mathrm{kg}^{-1}\right)$ & 24,700 & 28.1 & 3,950 & 8.83 \\
\hline & $\mathrm{Mn}\left(\mathrm{mg} \mathrm{kg}^{-1}\right)$ & 33,100 & 12.8 & 1.0 & 2.1 \\
\hline & $\mathrm{Ni}\left(\mathrm{mg} \mathrm{kg}^{-1}\right)$ & 0.75 & 8.9 & 41.5 & 17.9 \\
\hline & $\mathrm{Pb}\left(\mathrm{mg} \mathrm{kg}^{-1}\right)$ & 3.38 & 15.4 & 9.99 & 15.8 \\
\hline & $\mathrm{Zn}\left(\mathrm{mg} \mathrm{kg}^{-1}\right)$ & 1.1 & 18.1 & 59.0 & 22.9 \\
\hline & $\mathrm{Cl}\left(\mathrm{mg} \mathrm{kg}^{-1}\right)$ & 184 & 15.6 & 751 & 18.4 \\
\hline & $\mathrm{S}\left(\mathrm{mg} \mathrm{kg}^{-1}\right)$ & 846 & 16.7 & 900 & 15.6 \\
\hline \multicolumn{2}{|c|}{ Low heating value $\left(\mathrm{kcal} \mathrm{kg}^{-1}\right)$} & 5,340 & 22.1 & 5690 & 13.2 \\
\hline
\end{tabular}

Table 5. Concentrations of the pollutants in the flue gas.

\begin{tabular}{|c|c|c|c|c|c|}
\hline \multirow{2}{*}{ Item } & \multicolumn{2}{|c|}{ Group I (Coal) } & \multicolumn{2}{|c|}{ Group II (60\% Coal + 40\% SRF) } & \multirow{2}{*}{$\begin{array}{l}\text { Regulated } \\
\text { standard }\end{array}$} \\
\hline & Average & $\mathrm{RSD}(\%)$ & Average & $\mathrm{RSD}(\%)$ & \\
\hline $\mathrm{O}_{2}(\%)$ & 8.3 & 6.3 & 6.5 & 8.5 & - \\
\hline $\mathrm{CO}_{2}(\%)$ & 11.5 & 4.5 & 12.4 & 5.4 & - \\
\hline $\mathrm{CO}(\mathrm{ppm})$ & 45 & 10.1 & 35 & 17.4 & 350 \\
\hline $\mathrm{NO}_{\mathrm{x}}(\mathrm{ppm})$ & 160 & 18.5 & 120 & 12.3 & 220 \\
\hline $\mathrm{SO}_{x}(\mathrm{ppm})$ & 14 & 15.7 & 19 & 11.4 & 220 \\
\hline Particulate (mg Nm${ }^{-3}$ ) & 5.0 & 16.7 & 2.0 & 20.4 & 80 \\
\hline PCDD/Fs (ng I-TEQ $\mathrm{Nm}^{-3}$ ) & 0.0102 & 25.8 & 0.003 & 33.3 & 0.5 \\
\hline $\mathrm{Cd}\left(\mathrm{mg} \mathrm{Nm} \mathrm{N}^{-3}\right)$ & 0.00134 & 18.4 & 0.00128 & 17.7 & 0.04 \\
\hline $\mathrm{Cr}\left(\mathrm{mg} \mathrm{Nm} \mathrm{N}^{-3}\right)$ & 0.0147 & 12.6 & 0.0128 & 13.6 & - \\
\hline $\mathrm{Cu}\left(\mathrm{mg} \mathrm{Nm}^{-3}\right)$ & 0.00271 & 11.5 & 0.00133 & 22.4 & - \\
\hline $\mathrm{Hg}\left(\mathrm{mg} \mathrm{Nm} \mathrm{N}^{-3}\right)$ & 0.00021 & 10.8 & 0.00015 & 18.5 & 0.05 \\
\hline $\mathrm{Ni}\left(\mathrm{mg} \mathrm{Nm}^{-3}\right)$ & 0.00317 & 13.4 & 0.00656 & 21.1 & - \\
\hline $\mathrm{Pb}\left(\mathrm{mg} \mathrm{Nm}^{-3}\right)$ & 0.035 & 17.4 & 0.0122 & 15.6 & 0.5 \\
\hline
\end{tabular}

for Groups I and II remained excellent (99.96\% and 99.97\%) and were roughly equal. The average concentration of $\left[\mathrm{SO}_{2}\right]$ in the flue gas in Group II (19 ppm) was slightly higher than that in Group I (14 ppm). However, the concentrations were only about one order lower than the regulated standard (TEPA, 2020a). The [NO ${ }_{x}$ ] in the flue gas in Group I was 160 ppm, which was fairly close to the regulated standard (220 ppm), and it was slightly reduced to $120 \mathrm{ppm}$ in Group II (TEPA, 2020a). This can be explained by the fact that the $\left[\mathrm{O}_{2}\right]$ in Group II was further reduced to $6.5 \%$, and thus, the formation of thermal $\mathrm{NO}_{x}$ was partly reduced (see Eq. (2)).

$\mathrm{N}_{2}+\mathrm{O}_{2} \rightarrow 2 \mathrm{NO}$

When the coal was replaced with SRF, the PCDD/F concentrations in the flue gas were reduced from $0.01 \mathrm{ng}$ I-TEQ Nm${ }^{-3}$ (Group II) to $0.003 \mathrm{ng} \mathrm{I-TEQ} \mathrm{Nm}^{-3}$ (Group I), which were both much lower than the regulated standard $\left(0.5 \mathrm{ng} \mathrm{I-TEQ} \mathrm{Nm}^{-3}\right)$. The low PCDD/F level was attributed to excellent combustion efficiency and the injection of activated carbon, which was also reported in a previous study (Chen et al., 2020). Regarding the metal species, the concentrations in the flue gas in both groups were 1 to 2 orders lower than those specified in the regulated standard (TEPA, 2020a). 
The substitution of SRF for coal appeared to further reduce the concentrations of most of the metal species in the flue gas.

\subsection{Pollutant Composition in Mixed Fly Ashes}

Table 6 shows the PCDD/F content and metal composition of ashes in the two groups. Similar to the results of the flue gas analysis, the PCDD/F levels in the bottom ash $\left(0.0045 \mathrm{ng} \mathrm{I-TEQ} \mathrm{g}{ }^{-1}\right)$ and fly ashes $\left(0.0003 \mathrm{ng} \mathrm{I-TEQ} \mathrm{g}^{-1}\right)$ in Group II were slightly lower than those $\left(0.0049 \mathrm{ng} \mathrm{I-TEQ} \mathrm{g^{-1 }}\right.$ and 0.0005 ng I-TEQ $\mathrm{g}^{-1}$ ) in Group I. However, the PCDD/F levels of these ashes were all much lower than the regulated standard for hazardous materials (1 $\mathrm{ng} \mathrm{I-TEQ} \mathrm{g}^{-1}$ ) (TEPA, 2020b).

Fig. 4 shows the PCDD/F patterns of the flue gas, fly ashes, and bottom ash. For Group I, the $\mathrm{PCDD} / \mathrm{F}$ profiles for the flue gas and fly ashes were very similar, and the PCDD/F mass was mainly distributed in the form of OCDD, 1,2,3,4,6,7,8-HpCDF, 1,2,3,4,6,7,8-HpCDD, and OCDF. On the other hand, the PCDD/F mass of the bottom ash was mainly distributed in the form of OCDD (54.9\%), $1,2,3,4,6,7,8-H p C D D(14.8 \%)$, and OCDF (13.0\%). For Group II, the PCDD/F mass concentrations in the flue gas were mainly distributed in the form of $1,2,3,4,6,7,8-\mathrm{HpCDF}(22.4 \%)$, OCDF (20.8\%), and OCDD (18.1\%). The fly ashes mainly had PCDD/F mass concentrations in the form of OCDD $(27.8 \%)$ and $1,2,3,4,6,7,8-\mathrm{HpCDD}(38.2 \%)$. Similar to the bottom ash in Group I, the PCDD/F mass concentrations of the bottom ash in Group II were mainly in the form of OCDF (34.6\%), OCDD (17.0\%), 1,2,3,4,6,7,8-HpCDF (13.2\%), and 1,2,3,4,6,7,8-HpCDD (9.32\%). Overall, the PCDD/F mass concentrations in the two groups mainly existed as $7-\mathrm{Cl}$ and $8-\mathrm{Cl} \mathrm{PCDD} / \mathrm{Fs}$, and the addition of SRF did not make any significant difference.

\subsection{Mass Distribution and Emission Behavior of Pollutants among Output Materials}

Table 7 shows the mass distributions and emission factors of PCDD/Fs and heavy metals among the output materials. For Group I, the PCDD/Fs were mainly discharged from the fly ashes (61.8\%), for which the emission factor was 388 ng I-TEQ ton $^{-1}$. Similarly, the fly ashes also served as the main discharge route $(75.4 \%)$ in Group II, and the emission factor was further reduced to $232 \mathrm{ng} \mathrm{I-TEQ}$ ton $^{-1}$. The substitution of SRF for coal reduced the PCDD/F emissions by $40 \%$ but did not change the discharge route. This was probably due to the fact that SRF contains approximately $10 \%$ intra oxygen, which improves combustion and maintains the $\mathrm{O}_{2}$ in the flue gas at a relatively low concentration, thus retarding the formation of PCDD/Fs. In comparison to the results found in a previous study, the cogeneration plant emission factor was approximately 3 orders lower than that of the municipal solid waste incinerator, and the main discharge route was also from the fly ashes (Wang et al., 2010).

\subsection{Recycling Characteristics of the Ashes}

Table 8 shows the TCLP results for the ashes. In the case of both the bottom ash and fly ashes,

Table 6. PCDD/F content and metal composition of the ashes in both groups.

\begin{tabular}{|c|c|c|c|c|}
\hline \multirow{2}{*}{ Item } & \multicolumn{2}{|c|}{ Group I (Coal) } & \multicolumn{2}{|c|}{ Group II (Coal + SRF) } \\
\hline & Bottom ash & Fly ash & Bottom ash & Fly ash \\
\hline PCDD/Fs (ng I-TEQ g ${ }^{-1}$ ) & 0.0005 & 0.0049 & 0.0003 & 0.0045 \\
\hline $\mathrm{Al}\left(\mathrm{mg} \mathrm{kg}^{-1}\right)$ & 12,400 & 3,850 & 18,800 & 3,650 \\
\hline $\mathrm{Ca}\left(\mathrm{mg} \mathrm{kg}^{-1}\right)$ & 85,700 & 12,500 & 98,400 & 11,500 \\
\hline $\mathrm{Cd}\left(\mathrm{mg} \mathrm{kg}^{-1}\right)$ & 2.28 & 20.1 & 1.05 & 12.1 \\
\hline $\mathrm{Cr}\left(\mathrm{mg} \mathrm{kg}^{-1}\right)$ & 6.79 & 104 & 23.8 & 329 \\
\hline $\mathrm{Cu}\left(\mathrm{mg} \mathrm{kg}^{-1}\right)$ & 23.7 & 205 & 119 & 922 \\
\hline $\mathrm{Fe}\left(\mathrm{mg} \mathrm{kg}^{-1}\right)$ & 3,840 & 2,580 & 5,710 & 3,240 \\
\hline $\mathrm{Hg}\left(\mathrm{mg} \mathrm{kg}^{-1}\right)$ & 0.005 & 0.18 & 0.004 & 0.11 \\
\hline $\mathrm{Mn}\left(\mathrm{mg} \mathrm{kg}^{-1}\right)$ & 556 & 338 & 453 & 185 \\
\hline $\mathrm{Ni}\left(\mathrm{mg} \mathrm{kg}^{-1}\right)$ & 250 & 2.5 & 417 & 15.7 \\
\hline $\mathrm{Pb}\left(\mathrm{mg} \mathrm{kg}^{-1}\right)$ & 2.1 & 25.8 & 4.32 & 61.0 \\
\hline $\mathrm{Zn}\left(\mathrm{mg} \mathrm{kg}^{-1}\right)$ & 115 & 655 & 161 & 983 \\
\hline
\end{tabular}



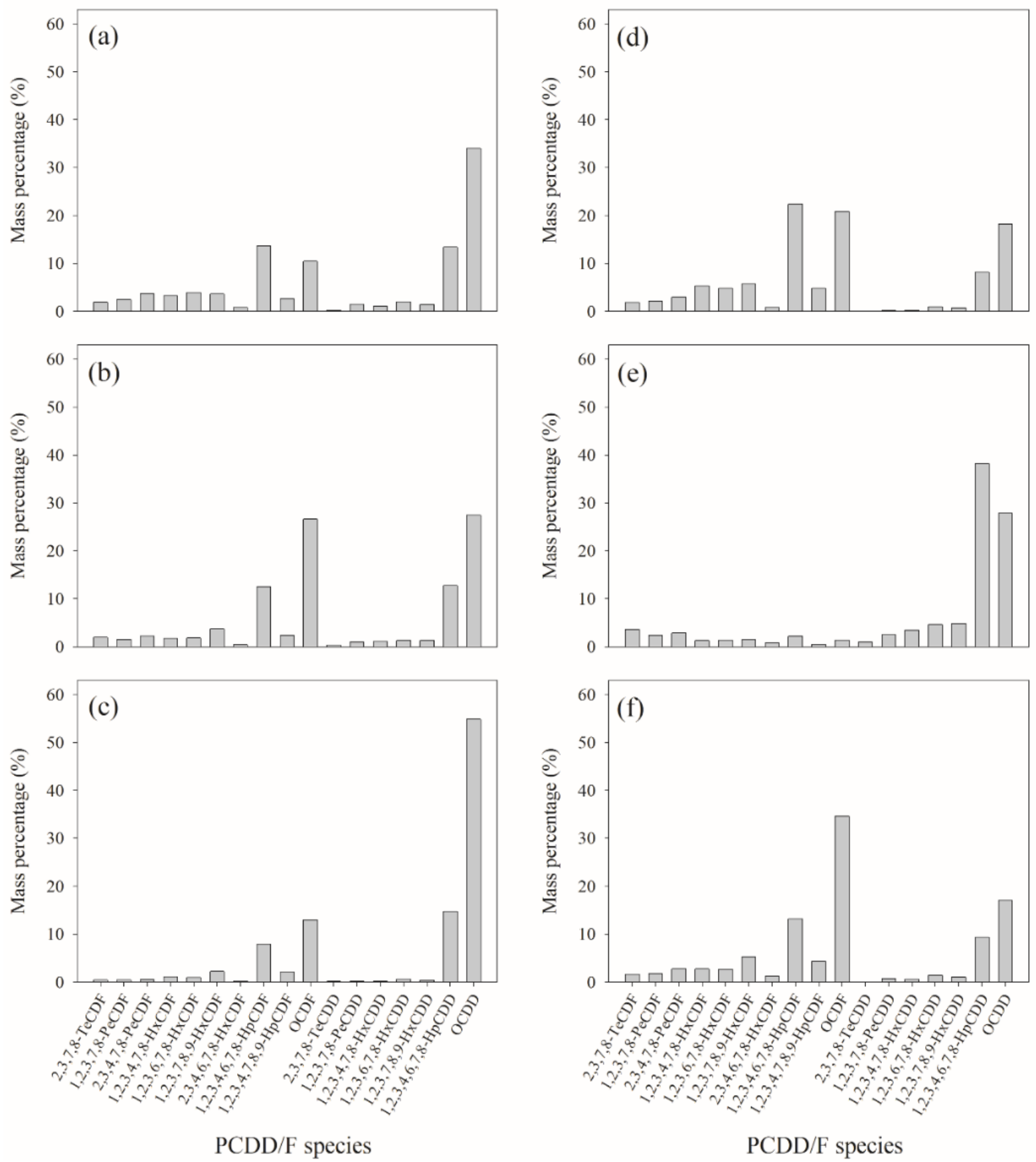

Fig. 4. PCDD/F patterns for the output materials: (a) flue gas (Group I); (b) fly ash (Group I); (c) bottom ash (Group I); (d) flue gas (Group II); (e) fly ash (Group II); (f) bottom ash (Group II).

Table 7. PCDD/Fs mass distribution, emission factors, and metals among the output materials for the two groups.

\begin{tabular}{|c|c|c|c|c|c|c|c|c|}
\hline \multirow[b]{2}{*}{ Item } & \multicolumn{4}{|c|}{ Group I (Coal) } & \multicolumn{4}{|c|}{ Group II (Coal + SRF) } \\
\hline & $\begin{array}{l}\text { Bottom ash } \\
(\%)\end{array}$ & $\begin{array}{l}\text { Fly ashes } \\
(\%)\end{array}$ & $\begin{array}{l}\text { Flue gas } \\
(\%)\end{array}$ & $\begin{array}{l}\text { Emission factor } \\
\left(\mathrm{mg} \mathrm{ton}^{-1}\right)\end{array}$ & $\begin{array}{l}\text { Bottom ash } \\
\text { (\%) }\end{array}$ & $\begin{array}{l}\text { Fly ashes } \\
\text { (\%) }\end{array}$ & $\begin{array}{l}\text { Flue gas } \\
(\%)\end{array}$ & $\begin{array}{l}\text { Emission factor } \\
\left(\mathrm{mg} \mathrm{ton}^{-1}\right)\end{array}$ \\
\hline $\mathrm{PCDD} / \mathrm{Fs}$ & 21.02 & 61.8 & 17.2 & 388 ng I-TEQ ton $^{-1}$ & 16.8 & 75.4 & 7.8 & 232 ng I-TEQ ton ${ }^{-1}$ \\
\hline $\mathrm{Cd}$ & 27.3 & 72.1 & 0.64 & 1,360 & 22.2 & 76.6 & 1.3 & 614 \\
\hline $\mathrm{Cr}$ & 17.6 & 80.9 & 1.53 & 6,290 & 19.3 & 80.2 & 0.5 & 15,900 \\
\hline $\mathrm{Hg}$ & 7.42 & 80.1 & 12.48 & 11.0 & 9.1 & 75.0 & 15.9 & 5.7 \\
\hline $\mathrm{Ni}$ & 99.7 & 0.30 & 0.05 & 40,900 & 98.8 & 1.1 & 0.1 & 54,600 \\
\hline $\mathrm{Pb}$ & 18.7 & 68.9 & 12.47 & 1,830 & 18.6 & 78.9 & 2.5 & 3,010 \\
\hline
\end{tabular}


Table 8. TCLP results for the ashes in both groups (units: in $\mathrm{mg} \mathrm{L}^{-1}$ ).

\begin{tabular}{|c|c|c|c|c|c|}
\hline \multirow{2}{*}{ Item } & \multicolumn{2}{|c|}{ Group I (Coal) } & \multicolumn{2}{|c|}{ Group II (Coal + SRF) } & \multirow{2}{*}{$\begin{array}{l}\text { Regulated } \\
\text { standard }\end{array}$} \\
\hline & Bottom ash & Fly ashes & Bottom ash & Fly ashes & \\
\hline As & 0.17 & 0.034 & 0.12 & 0.025 & 5.0 \\
\hline $\mathrm{Ba}$ & 0.31 & 0.15 & 0.23 & 0.11 & 100 \\
\hline $\mathrm{Cd}$ & N.D. & N.D. & N.D. & N.D. & 1.0 \\
\hline $\mathrm{Cr}$ & 0.45 & 0.115 & 0.11 & 0.02 & 5.0 \\
\hline $\mathrm{Cu}$ & 0.55 & 0.1 & 0.38 & N.D. & 15.0 \\
\hline $\mathrm{Hg}$ & N.D. & N.D. & N.D. & N.D. & 0.2 \\
\hline $\mathrm{Pb}$ & N.D. & N.D. & N.D. & N.D. & 5.0 \\
\hline Se & N.D. & N.D. & N.D. & N.D. & 1.0 \\
\hline
\end{tabular}

Table 9. Metal oxide content in the ashes for Group I and Group II (units: in \%).

\begin{tabular}{llllll}
\hline \multirow{2}{*}{ Item } & \multicolumn{2}{c}{ Group I } & & \multicolumn{2}{c}{ Group II } \\
\cline { 2 - 3 } \cline { 5 - 6 } & Bottom ash & Fly ash & & Bottom ash & Fly ash \\
\hline $\mathrm{Al}_{2} \mathrm{O}_{3}$ & 28.7 & 21.4 & 26.6 & 20.88 \\
$\mathrm{CaO}$ & 0.572 & 4.17 & 0.997 & 5.88 \\
$\mathrm{Fe}_{2} \mathrm{O}_{3}$ & 2.17 & 4.87 & 3.23 & 5.45 \\
$\mathrm{SiO}_{2}$ & 64.1 & 50.84 & & 65.8 & 43.45 \\
$\mathrm{Cl}$ & 0.0015 & 0.018 & & 0.0036 & 0.0125 \\
\hline
\end{tabular}

the leaching concentrations of the metals in both groups were all N.D. or much lower than the regulated standard for hazardous materials (TEPA, 2020b). The leaching concentrations of the ashes in Group II were slightly lower than those in Group I. In addition, the PCDD/F content in the ashes was lower than the regulated standard of hazardous materials, as previously mentioned. Therefore, the bottom ash and fly ashes were classified as non-hazardous materials and could be directly recycled as building materials. Table 9 shows the $\mathrm{Al}, \mathrm{Ca}, \mathrm{Fe}$, and Si oxides in the bottom ash and fly ashes. For the bottom ash, $\mathrm{SiO}_{2}$ accounted for $64.1 \%$ and $65.8 \%$ in groups I and II, respectively. Next to $\mathrm{SiO}_{2}$, the fractions of $\mathrm{Al}_{2} \mathrm{O}_{3}$ were $28.7 \%$ and $26.6 \%$ in Groups I and II, respectively. The percentages of $\mathrm{Fe}_{2} \mathrm{O}_{3}$ and $\mathrm{CaO}$ were both less than $5 \%$. For the fly ashes, $\mathrm{SiO}_{2}$ was still the main oxide in both Groups I (50.84\%) and II (43.45\%), and $\mathrm{Al}_{2} \mathrm{O}_{3}$ was also the secondary oxide in Groups I (21.4\%) and II (20.88\%). The percentages of $\mathrm{CaO}$ and $\mathrm{Fe}_{2} \mathrm{O}_{3}$ were all approximately $5 \%$. For recycling as the raw materials in cement, the total $\mathrm{Al}_{2} \mathrm{O}_{3}, \mathrm{CaO}, \mathrm{Fe}_{2} \mathrm{O}_{3}$, and $\mathrm{SiO}_{2}$ is required to be higher than $85 \%$. The bottom ashes met this requirement, but the fly ashes did not. Therefore, the bottom ashes could be directly recycled as an additive of cement. On the other hand, the cementation of fly ashes to form other building materials, such as road pavement, could be taken into consideration.

\subsection{Economic Analysis for Recovering Waste Lubricant and Reclamation of SRF}

Table 10 shows the results for the economic analysis of the recovery of waste lubricant. The treatment plant can obtain a treatment income of 260 USD ton ${ }^{-1}$ from the food-can factory. 0.17 of a ton of wastewater was discharged during the treatment of 1 ton of waste lubricant, and the treatment cost for the wastewater was 30 USD ton ${ }^{-1}$. The cost of the additives for SRF, including wood dust, bentonite, and coal ash was 50, 100, and -20 USD ton ${ }^{-1}$, respectively. The price at which it was sold to the cogeneration plant was 30 USD ton ${ }^{-1}$, which was the income for the treatment plant. Recovery of 1 ton of waste lubricant produced 1.381 tons of SRF, and the operating cost for the SRF was about 80 USD ton $^{-1}$. The net revenue for recovering 1 ton of waste lubricant was 119 USD ton ${ }^{-1}$. The capacity of this treatment plant was 30 tons day ${ }^{-1}$, and the operating days were 300 days per year. Therefore, the annual gross revenue for this treatment plant was 1,071,000 USD.

The heating value of the $\operatorname{SRF}\left(5,690 \mathrm{kcal} \mathrm{kg}^{-1}\right)$ was approximately equal to that of coal $(5,340$ $\mathrm{kcal} \mathrm{kg}^{-1}$ ), but the price was about half ( 32 USD ton ${ }^{-1}$ ) that of coal ( 60 USD ton $\left.{ }^{-1}\right)$. The capacity of the cogeneration plant was 2 tons coal feeding per hour, where with a $50 \%$ replacement of coal 
Table 10. Economic analysis of recovery of waste lubricant.

\begin{tabular}{|c|c|c|c|c|}
\hline Item & $\begin{array}{l}\text { Mass } \\
\text { (ton) }\end{array}$ & $\begin{array}{l}\text { Price } \\
(\text { USD ton }\end{array}$ & $\begin{array}{l}\text { Income/Outcome } \\
\text { (USD) }\end{array}$ & Annotation \\
\hline Waste lubricant & 1 & 260 & +260 & Treatment fee from food-can factory \\
\hline Treated lubricant & 0.83 & - & - & \\
\hline Wastewater & 0.17 & 30 & -51 & Wastewater treatment cost \\
\hline Wood dust & 0.484 & 50 & -24.2 & \\
\hline Bentonite & 0.007 & 100 & -0.7 & \\
\hline Coal ash & 0.06 & 20 & 1.2 & \\
\hline Operating cost & 1.381 & 80 & -110.5 & $\begin{array}{l}\text { Operating costs for } 1 \text { ton of SRF (including electricity, } \\
\text { water, manpower, and maintenance of facility) }\end{array}$ \\
\hline SRF & 1.381 & 32 & 44.2 & Income of selling SRF to cogeneration plant \\
\hline Net revenue & - & - & 119 & \\
\hline
\end{tabular}

with SRF, it was 1 ton $\mathrm{hr}^{-1}$. The cogeneration plant was operated $24 \mathrm{hrs}$ a day, 330 days per year. The savings for fuel was as high as 221,760 USD per year. Therefore, the substitution of SRF for coal was feasible from an economic point of view.

\section{CONCLUSIONS}

In this study, the combustion performance of coal and was compared with a mixture of coal and SRF in a cogeneration plant. There were several conclusions drawn suggesting that it is feasible to replace coal with this SRF transformed from recovered waste lubricant as follows:

1. For Group I ( $100 \%$ coal), the concentration of the pollutants in the flue gas was much lower than the regulated standard, with the exception of $\left[\mathrm{NO}_{\mathrm{x}}\right]$.

2. In the scenario where $40 \%$ of the coal was replaced with SRF, the concentrations of $\mathrm{NO}_{\mathrm{x}}$ and PCDD/Fs in the flue gas were $25 \%$ and $70 \%$, respectively.

3. The PCDD/F emission factor in the cogeneration plant was 3 orders lower than that in the municipal solid waste incinerator. The substitution of SRF for coal further reduced the PCDD/F emissions by $40 \%$.

4. The bottom ash and fly ashes from this cogeneration plant were considered general industrial waste and could be directly recycled as a cement additive.

5. The treatment plant could obtain a net revenue of 119 USD ton ${ }^{-1}$ from recovering waste lubricant. The replacement of coal with SRF could decrease the consumption of coal and increase the profits for the plant.

6. The pollution characteristics of this plant were slightly improved by substitution of SRF, and the ashes still could be directly recycled as cement additives.

\section{REFERENCES}

Arena, U., Mastellone, M.L., Perugini, F. (2003). The environmental performance of alternative solid waste management options. Chem. Eng. J. 96, 207-222. https://doi.org/10.1016/j.cej.20 03.08.019

Arena, U. (2012). Process and technological aspects of municipal solid waste gasification. A review. Waste Manage. 32, 625-639. https://doi.org/10.1016/j.wasman.2011.09.025

Azapagic, A., Perdan, S., Clift, R. (2004). Sustainable development in practice. J. Wiley \& Sons. Ltd., Chicester, UK.

Chang, C.J., Yang, H.H. (2020). Impact on eye health regarding gaseous and particulate pollutants. Aerosol Air Qual. Res. 20, 1695-1699. https://doi.org/10.4209/aaqr.2020.03.0098

Chang, N.B., Wang, H.P., Huang, W.L., Lin, K.S. (1999). The assessment of reuse potential for municipal solid waste and refuse-derived fuel incineration ashes. Resour. Conserv. Recycl. 25, 255-270. https://doi.org/10.1016/S0921-3449(98)00066-4

Chen, S., Cui, K., Zhao, Y., Yin, Z., Chao, H.R., Chang-Chien, G.P. (2018). Sensitivity analysis of 
atmospheric $\mathrm{PM}_{2.5}$-bound content and dry deposition of total PCDD/Fs-TEQ: In the case of Xiamen and Zhangzhou, China. Aerosol Air Qual. Res. 18, 3096-3114. https://doi.org/10.4209/ aaqr.2018.11.0393

Chen, T., Sun, C., Wang, T., Zhan, M., Li, X., Lu, S., Yan, J. (2020). Removal of PCDD/Fs and CBzs by different air pollution control devices in MSWIs. Aerosol Air Qual. Res. 20, 2260-2272. https://doi.org/10.4209/aaqr.2019.10.0536

Consonni, S., Giugliano, M., Grosso, M. (2005). Alternative strategies for energy recovery from municipal solid waste. Part A: Mass and energy balances. Waste Manage. 25, 123-135. https://doi.org/10.1016/j.wasman.2004.09.007

Directive 2008/98/EC of the European Parliament and of the Council on Waste and Repealing Certain Directives - Annex II, 19 November 2008.

Gug, J., Cacciola, D., Sobkowicz, M.J. (2015). Processing and properties of a solid energy fuel from municipal solid waste (MSW) and recycled plastics. Waste Manage. 35, 283-292. https://doi.org/10.1016/j.wasman.2014.09.031

Kuo, Y.M., Wang, Y.K., Lin, S.L., Yin, L.T., Hsieh, Y.K. (2019). Air Pollution characteristics of reclamation of refuse derived fuel (RDF) recovered from cutting oil waste. Aerosol Air Qual. Res. 19, 2576-2584. https://doi.org/10.4209/aaqr.2019.09.0481

Leme, M.M.V., Rocha, M.H., Lora, E.E.S., Venturini, O.J., Lopes, B.M., Ferreira, C.H. (2014). Technoeconomic analysis and environmental impact assessment of energy recovery from municipal solid waste (MSW) in Brazil. Resour. Conserv. Recycl. 87, 8-20. https://doi.org/10.1016/j.resco nrec.2014.03.003

Lombardi, L., Carnevale, E., Corti, A. (2015). A review of technologies and performances of thermal treatment systems for energy recovery from waste. Waste Manage. 37, 26-44. https://doi.org/10.1016/j.wasman.2014.11.010

Murer, M.J., Spliethoff, H., De Waal, C.M.W., Wilpshaar, S., Berkhout, B., Van Berlo, M.A.J, Gohlke, O., Martin, J.J.E. (2011). High efficient waste-to-energy in Amsterdam: Getting ready for the next steps. Waste Manage. Res. 29, 20-29. https://doi.org/10.1177/0734242X11413334

Myrin, E.S., Persson, P.E., Jansson, S. (2014). The influence of food waste on dioxin formation during incineration of refuse-derived fuels. Fuel 132, 165-169. https://doi.org/10.1016/j.fuel. 2014.04.083

Nam-Chol, O., Kim, W.G. (2017). Investigation of characterization of municipal solid waste for refused-derived fuel, a case study. Energy Sources Part A 39, 1671-1678. https://doi.org/10.10 80/15567036.2017.1367869

Nasrullah, M., Vainikka, P., Hannula, J., Hurme, M., Kärki, J. (2015). Mass, energy and material balances of SRF production process. Part 3: Solid recovered fuel produced from municipal solid waste. Waste Manage. Res. 33, 146-156. https://doi.org/10.1177/0734242X14563375

Psomopoulos, C.S., Bourka, A., Themelis, N.J. (2009). Waste-to-energy: A review of the status and benefits in USA. Waste Manage. 29, 1718-1724. https://doi.org/10.1016/j.wasman.2008.11.020

Qiu, J., Tang, M., Peng, Y., Lu, S., Li, X., Yan, J. (2020). Characteristics of PCDD/Fs in flue gas from MSWIs and HWIs: Emission levels, profiles and environmental influence. Aerosol Air Qual. Res. 20, 2085-2097. https://doi.org/10.4209/aaqr.2019.11.0610

Rada, E.C., Andreottola, G. (2012). RDF/SRF: which perspective for its future in the EU. Waste Manage. 32, 1059-1060. https://doi.org/10.1016/j.wasman.2012.02.017

Taiwan Environmental Protection Administration (TEPA) (2006). Standard Method of Detection of Heavy Metals in Outlet Line; NIEA A302.72C; Taiwan Environmental Protection Administration, Taiwan.

Taiwan Environmental Protection Administration (TEPA) (2010). Standard Sampling Method for PCDD/Fs of Flue Gas; NIEA A807.75C. Taiwan Environmental Protection Administration, Taiwan.

Taiwan Environmental Protection Administration (TEPA) (2014). Standard Method for Analyzing Heavy Metals in Extracts from Industrial Waste Acid Digestion with Microwave. NIEA R317.11C. Taiwan Environmental Protection Administration, Taiwan.

Taiwan Environmental Protection Administration (TEPA) (2016). Toxicity Characteristic Leaching Procedure; NIEA R201.15C. Taiwan Environmental Protection Administration, Taiwan.

Taiwan Environmental Protection Administration (TEPA) (2020a). Pollutants Emission Regulated Standards for Boilers. Taiwan Environmental Protection Administration, Taiwan. 
Taiwan Environmental Protection Administration (TEPA) (2020b). Standards for Defining Hazardous Industrial Waste. Taiwan Environmental Protection Administration, Taiwan.

Tsai, J.H., Chen, S.J., Li, P.M., Chang-Chien, G.P., Huang, K.L., Tsai, C.H., Hsieh, C.Y., Lin, C.C. (2018). Characteristics of PM2.5-bound PCDD/Fs, PCBs, PBDD/Fs and PBDEs from a diesel generator using waste cooking oil-based biodiesel blends. Aerosol Air Qual. Res. 18, 2583-2590. https://doi.org/10.4209/aaqr.2018.08.0310

Vermeulen, I., Caneghem, V.J., Block, C., Baeyens, J., Vandecasteel, C. (2011). Automotive shredder residue (ASR): Reviewing its production from end-of-life vehicles (ELVs) and its recycling, energy or chemicals' valorization. J. Hazard. Mater. 190, 8-27. https://doi.org/10.10 16/j.jhazmat.2011.02.088

Wang, L.C., His, H.C., Wang, Y.F., Lin, S.L., Chang-Chien, G.P. (2010). Distribution of polybrominated diphenyl ethers (PBDEs) and polybrominated dibenzo- $p$-dioxins and dibenzofurans (PBDD/Fs) in municipal solid waste incinerators. Environ. Pollut. 158, 1595-1602. https://doi.org/10.1016/ j.envpol.2009.12.016

Yue, T., Wang, K., Wang, C., Tong, Y., Gao, J., Zhang, X., Zuo, P., Tong, L., Liang, Q. (2020). Emission characteristics of hazardous atmospheric pollutants from ultra-low emission coal-fired industrial boilers in China. Aerosol Air Qual. Res. 20, 877-888. https://doi.org/10.4209/aaqr.20 19.10.0531

Zhou, C., Zhang, Q., Arnold, L., Yang, W., Blasiak, W. (2013). A study of the pyrolysis behaviors of pelletized recovered municipal solid waste fuels. Appl. Energy 107, 173-182. https://doi.org/1 0.1016/j.apenergy.2013.02.029 